Vol. 9 (2000): 187-200.

\title{
Feeding levels during the growing phase affect the production of primiparous Finnish Landrace ewes
}

\author{
Riitta Sormunen-Cristian \\ Agricultural Research Centre of Finland, Animal Production Research, FIN-31600 Jokioinen, Finland, \\ e-mail: riitta.sormunen-cristian@mtt.fi
}

Lauri Jauhiainen

Agricultural Research Centre of Finland, Data and Information Services, FIN-31600 Jokioinen, Finland

\begin{abstract}
The effect of different feeding levels on the performance of primiparous ewes was studied in 31 Finnish Landrace ewes bred to lamb at the age of one year. Ewe lambs, initially weighing on average $19.2 \mathrm{~kg}$ (SEM 0.63), were placed on a low (L), standard (S) or high $(\mathrm{H})$ level of feeding from 2 months of age to the end of mating and from 2 months pre-partum to the end of 8-week lactation. Changes in live weight were affected by the diet. During rearing, the ewe lambs on L diet gained significantly less $(18.0$ vs. $24.1 \mathrm{~kg} / \mathrm{lamb}, \mathrm{P}<0.0001)$ and they were also significantly lighter at mating than those on $\mathrm{H}$ diet $(47.8$ vs. $54.1 \mathrm{~kg} / \mathrm{lamb}, \mathrm{P}<0.01)$. Excluding ewe lambs on $\mathrm{L}$ diet, mating was successful. The highest litter size (4 lambs/ewe) occurred on $\mathrm{H}$ diet. Intensive feeding did not have a negative effect on milk yield. Ewes on S diet tended to produce the most milk, but the differences between diets were not significant. A high feeding level decreased the fat content, but its influence on the protein content of milk was small. It was suggested that replacement ewe lambs can be reared together with market lambs. The official Finnish feeding recommendations for sheep seemed to be unnecessarily high.
\end{abstract}

Key words: ewe lamb, growth rate, milk composition, milk yield, nutrition, sheep

\section{Introduction}

Prepubertal female lambs have a period of accelerated mammary parenchymal growth ending at about 4 months of age (Anderson 1975). During that critical period, high level of nutrition may inhibit the mammary parenchymal growth and reduce milk yield of ruminants at maturity (Gould and Whiteman 1975, Johnsson and Hart 1985, Foldager and Sejrsen 1991). Also too low level of nutrition before mating has had a negative effect on the productivity of ewes (Kassem et al. 1989). In several studies, ewe lambs reared on a low level showed delayed onset of oestrus or totally failed to exhibit oestrus in the first year 


\section{AGRICULTURAL AND FOOD SCIENCE IN FINLAND}

Sormunen-Cristian, R. \& Jauhiainen, L. Feeding levels during the growing phase of Finnish landrace ewes

(Younis et al. 1978, Kassem et al. 1989). The delay has been associated with diets deficient in energy, protein or both.

Typically, $18 \%$ of the spring-born ewe lambs in Finland are kept for replacement and $100 \%$ of these are bred to lamb as yearlings. In practice, all female and male lambs are reared together and fed intensively since no particular nutrient recommendations are available for breeding lambs in Finland (Salo et al. 1990, Tuori et al. 1996). Thus, the productive performance of primiparous Finnish Landrace ewes is suspected to be low due to the negative effects of intensive feeding. As long as reproductive performance is not reduced, ewe lambs could remain with market lambs, which would reduce labour and space requirements, and also permit selection of replacement females when the animals are older and larger.

The relationship between early ewe lamb nutrition and subsequent productivity for primiparous and multiparous Finnish Landrace ewes lambing at the age of one year has not been reported earlier. Furthermore, there is little information on the milk yield and quality of ewes suckling in their first lactation. The present study was designed to evaluate the productive performance of Finnish Landrace ewe lambs fed different dietary energy and protein levels from weaning through breeding and during late gestation and 8 -week lactation.

\section{Material and methods}

\section{Animals, their feeding and management}

Thirty-one pure-bred Finnish Landrace ewe lambs born between 8 and 20 March, and weaned at the age of 56 days were used in the experiment. The lambs were penned individually indoors and they commenced the experiment after weaning in May. The basic management of unweaned lambs and their dams has been described in detail by Sormunen-Cristian et al. (1997). The study was carried out at the Sheep Research Sta- tion of the Agricultural Research Centre of Finland in Jokioinen $\left(60^{\circ} 54^{\prime} \mathrm{N}, 2^{\circ} 30^{\prime} \mathrm{E}, 107 \mathrm{~m}\right.$ above sea level).

From weaning to the age of 23 weeks ewe lambs were given a mixture of concentrates (barley grain $77 \rightarrow 86 \%$ and soya bean meal $23->$ $14 \%$ ) as follows: feeding group L (low level) 54 g dry matter (DM)/kg metabolic live weight $\left(\mathrm{W}^{0.75}\right)$, feeding group $\mathrm{S}$ (standard level) $63 \mathrm{~g}$ $\mathrm{DM} / \mathrm{kgW}^{0.75}$ and feeding group $\mathrm{H}$ (high level) 72 $\mathrm{g} \mathrm{DM} / \mathrm{kgW}^{0.75}$. Group L received $14 \%$ less and group $\mathrm{H} 14 \%$ more energy and protein in the concentrates than group S. Chopped hay made from timothy (Phleum pratense L.) - meadow fescue (Festuca pratensis Huds.) grass was given ad libitum. Mineral mixture $(\mathrm{Ca}: \mathrm{P}=2: 1)$, calcium carbonate $\left(\mathrm{CaCO}_{3}\right)$ and salt $(\mathrm{NaCl})$ were added in the concentrates $20 \mathrm{~g}, 15 \mathrm{~g}$ and $10 \mathrm{~g} /$ lamb/day, respectively. The ewe lambs completed their growing test at the age of 23 weeks when the appropriate slaughter weight was reached.

During the 10-week mating (16 Sep - 24 Nov), all ewe lambs received concentrates $70 \%$ (54 $\mathrm{g} \mathrm{DM} / \mathrm{kgW}^{0.75}$ ) of the total DM intake for combined maintenance and flushing (Salo et al. 1990). From concentrates, group L received $14 \%$ less and group $\mathrm{H} 14 \%$ more crude protein $(\mathrm{CP})$ than group $\mathrm{S}$. The amount of CP for groups L, S and $\mathrm{H}$ was 106,123 and $140 \mathrm{~g} /$ fattening feed unit (FFU $=0.7 \mathrm{~kg}$ starch equivalent), respectively.

During early gestation, all ewe lambs were fed similarly. Concentrate supplement (106 g CP in FFU) was offered at 500 grams/lamb/day. During the last 2 months of pregnancy, ewe lambs on the $\mathrm{L}, \mathrm{S}$ and $\mathrm{H}$ diets received concentrates $(185 \mathrm{~g}$ $\mathrm{CP} / \mathrm{FFU}$ ) at levels of 500,550 and $600 \mathrm{~g} / \mathrm{lamb} /$ day, respectively, and during lactation at levels of 360,420 and $480 \mathrm{~g} /$ suckling lamb/day, respectively. The concentrate rations were kept unchanged throughout the lactation period.

\section{Experimental procedures and analytical methods}

The ewe lambs were exposed to rams when they were 225 days (SD 3.7) old. A vasectomized 
Vol. 9 (2000): 187-200.

Table 1. Chemical composition and feed values of the experimental feeds offered during rearing (1), 8 weeks pre-partum (2) and lactation (3).

\begin{tabular}{|c|c|c|c|c|c|c|}
\hline \multirow{3}{*}{$\begin{array}{l}\text { Period } \\
\text { Number of samples }\end{array}$} & \multicolumn{3}{|c|}{ Timothy-fescue hay } & \multicolumn{3}{|c|}{ Concentrate } \\
\hline & 1 & 2 & 3 & 1 & 2 & 3 \\
\hline & 7 & 4 & 3 & 7 & 3 & 3 \\
\hline Dry matter $(\mathrm{DM}), \mathrm{g} / \mathrm{kg}$ & 839 & 808 & 862 & 881 & 889 & 880 \\
\hline \multicolumn{7}{|l|}{ In DM, g/kg } \\
\hline Organic matter & 929 & 926 & 923 & 966 & 965 & 964 \\
\hline Crude protein & 104 & 104 & 109 & 197 & 210 & 199 \\
\hline Ether extract & 21 & 24 & 24 & 22 & 19 & 19 \\
\hline Crude fibre & 327 & 322 & 351 & 55 & 58 & 64 \\
\hline Digestible organic matter & 604 & 606 & 604 & 617 & 783 & 781 \\
\hline \multicolumn{7}{|l|}{ Feed values $/ \mathrm{kg} \mathrm{DM}$} \\
\hline Net energy, FFU & 0.58 & 0.58 & 0.55 & 0.85 & 1.08 & 1.07 \\
\hline $\mathrm{ME}, \mathrm{FU}$ & 0.78 & 0.79 & 0.78 & 0.84 & 1.07 & 1.07 \\
\hline $\mathrm{ME}, \mathrm{MJ}$ & 9.16 & 9.19 & 9.17 & 9.83 & 12.5 & 12.49 \\
\hline AAT, $\mathrm{g}$ & 64 & 65 & 65 & 100 & 121 & 117 \\
\hline PBV, $\mathrm{g}$ & -30 & -31 & -27 & 37 & 15 & 12 \\
\hline
\end{tabular}

$\mathrm{FFU}=$ fattening feed unit $(0.7 \mathrm{~kg}$ starch equivalent $) ; \mathrm{ME}=$ metabolizable energy; $\mathrm{FU}=$ feed unit $(\mathrm{ME} \mathrm{MJ} / 11.7) ; \mathrm{AAT}=\mathrm{amino}$ acids absorbed from the small intestine; PBV=protein balance in the rumen.

adult ram equipped with a crayon harness was used for the detection of behavioural oestrus ( 5 Oct -18 Nov). The ewe lambs found in oestrus were hand-mated with a fertile Finnish Landrace ram and returned to their respective feeding groups.

The live weights of the ewe lambs were recorded at the beginning of the study and subsequently at 2-week intervals. In addition, they were weighed 7, 2 and one day before lambing and 24 and 48 hours after parturition and at weekly intervals during lactation. Their lambs were weighed at parturition, at the age of 3 days and on the same days with their dams during the lactation.

The ewe lambs were culled only when physical conditions deteriorated seriously.

Individual feed intake was recorded daily. The lambs and ewes were given hay once and concentrates twice a day during the rearing and lactation periods. Feed samples were taken at every feeding and pooled over a 2-week period. The samples were analyzed according to stand- ard procedures (AOAC 1984). In vivo digestibility of hay and concentrates was determined by the total collection method with three wethers. Feed values were calculated on the basis of chemical composition and digestibility of feeds. Net energy (NE) of feeds was calculated as FFU according to Salo et al. (1990) and metabolizable energy (ME) according to MAFF (1975). The feed unit (FU) was obtained by dividing the ME value by 11.7 (Tuori et al. 1996). Protein intake was calculated in terms of amino acids absorbed in the small intestine (AAT) and protein balance in the rumen (PBV) (Tuori et al. 1996). In the AAT-PBV calculations, the degrability of crude protein was taken from the feed tables (Tuori et al. 1996). The chemical compositions and feeding values of the feeds are given in Table 1 .

The milk yield was estimated by measuring the secretion rate over a 4 -h period by intramuscular oxytocin injection $(5 \mathrm{IU} / \mathrm{ml})$ as outlined by McCance (1959). The ewes were milked by hand 6 times a week for 8 lactation weeks. Representative milk samples from two days' milking were 
Sormunen-Cristian, R. \& Jauhiainen, L. Feeding levels during the growing phase of Finnish landrace ewes

taken, pooled and analysed weekly for fat and protein by the same methods as described by Sormunen-Cristian et al. (1997).

\section{Statistical methods}

Measurements of live weight of ewe lambs, milk yield, as well as fat and protein content of milk were repeated several times for each animal. The repeated measurements of each response variable were correlated and the correlation was taken into account in the statistical models. Covariance structure for the repeated measurements was chosen, comparing all biologically sensible structures using Akaike's and Schwarz's Bayesian information criteria (Wolfinger 1996). Unstructured, Toeplitz, compound symmetry and heterogeneous Toeplitz proved useful for live weight of ewe lambs, milk yield and fat and protein content of milk, respectively.

Thirty-six dams of ewe lambs were randomly allotted to three feeding groups as described earlier (Sormunen-Cristian et al. 1997). Due to the randomization method the mean of twin ewe lambs of each dam was used as the experimental unit instead of individual values. There were only four pairs of twins at the end of the study. Hence, the response variable (Y) was analysed according to the following statistical model:

$$
\mathrm{Y}_{\mathrm{ijk}}=\underset{\varepsilon_{\mathrm{ijk}}}{\mu}+\text { dam }_{\mathrm{j}}+\text { diet }_{\mathrm{i}}+\text { time }_{\mathrm{k}}+\left(\operatorname{diet} \times \text { time }_{\mathrm{ik}}+\right.
$$

where $\mu$ is the intercept and dam ${ }_{\mathrm{j}}$ represents the normally distributed random effect associated with the jth dam. Diet ${ }_{i}$ time $_{k}$ and (diet $\times$ time $)_{\mathrm{ik}}$ represent the fixed effect associated with the jth feeding group, kth time and their interaction, respectively. $\varepsilon_{\mathrm{ijk}}$ are correlated residual errors with covariance structure defined above. $\varepsilon_{\mathrm{ijk}}$ and dam $_{\mathrm{j}}$ are mutually independent.

Litter weight was measured only at birth. Thus the statistical model included $\mu, \operatorname{diet}_{\mathrm{i}}$, dam $_{\mathrm{j}}$ and $\varepsilon_{\mathrm{ij}}$ and the residual errors are independent and normally distributed with zero means and the same unknown variance $\sigma^{2}$.
Assumptions of the models were checked by using graphical methods: box-plot for normality of errors and plots of residuals for constancy of error variance (Neter et al. 1996). Pairwise comparisons were made between the three levels of feeding. The milk yield and milk composition, comparisons between diet means were made also by orthogonal trend contrasts. The parameters of the models were estimated by the restricted maximum likelihood (REML) estimation method using the SAS system for Windows, release 6.12, and MIXED procedure.

\section{Results and discussion}

\section{Feed intake}

The average daily nutrient intakes during rearing and mating are summarised in Table 2. From weaning to 23 weeks of age ewe lambs on $\mathrm{H}$ diet consumed 14\% more energy (ME MJ) and 16\% more protein (AAT g) on average than those on $\mathrm{S}$ diet. The differences between $\mathrm{L}$ and $\mathrm{S}$ diets were lower, only 4 and $8 \%$, respectively. The smaller differences resulted from the different substitution rates. Increasing concentrate supplementation from 54 to 63 and from 63 to $72 \mathrm{~g}$ $\mathrm{DM} / \mathrm{kgW}^{0.75}$ reduced hay intake at a substitution rate of 0.67 and 0.19 , respectively. During rearing, ewe lambs on $\mathrm{L}, \mathrm{S}$ and $\mathrm{H}$ diets consumed concentrates 0.65 (SD 0.062), 0.77 (SD 0.102.) and 0.93 (SD 0.117) kg DM/lamb/day, respectively, on average. The concentrate intake was $43 \%$ higher on $\mathrm{H}$ diet than on $\mathrm{L}$ diet. This decreased the hay intake so that the concentrate:forage ratio was 80:20 on $\mathrm{H}$ diet, whereas on $\mathrm{L}$ diet it was $65: 35$. According to Owen (1976), the roughage:concentrate ratio on $\mathrm{H}$ diet was ideal to ensure maximum DM intake. Expressed on a metabolic body weight basis, total DM intake on $\mathrm{L}, \mathrm{S}$ and $\mathrm{H}$ diets averaged 82,82 and $88 \mathrm{~g} / \mathrm{kgW}^{0.75}$, respectively.

In Finland there are no feeding standards for 
Vol. 9 (2000): 187-200.

Table 2. Daily nutrient intake of primiparous ewe lambs during rearing and mating. In each figure pair, the upper figure is the mean and the lower is the standard deviation.

\begin{tabular}{|c|c|c|c|c|c|c|}
\hline \multirow[b]{2}{*}{ Diet } & \multicolumn{3}{|c|}{ Rearing from 8 to 23 weeks } & \multicolumn{3}{|c|}{ Mating from 26 to 36 weeks } \\
\hline & $\mathrm{L}$ & S & $\mathrm{H}$ & $\mathrm{L}$ & S & $\mathrm{H}$ \\
\hline Number of ewes & 11 & 10 & 10 & 10 & 10 & 9 \\
\hline \multirow{2}{*}{ Forage, $\mathrm{kg} \mathrm{DM}$} & 0.34 & 0.26 & 0.23 & 0.36 & 0.28 & 0.25 \\
\hline & 0.106 & 0.053 & 0.044 & 0.129 & 0.060 & 0.059 \\
\hline \multirow[t]{2}{*}{ Total DM, kg } & 1.00 & 1.03 & 1.17 & 1.27 & 1.27 & 1.29 \\
\hline & 0.155 & 0.131 & 0.143 & 0.154 & 0.125 & 0.144 \\
\hline \multirow[t]{2}{*}{ Organic matter $(\mathrm{OM}), \mathrm{kg}$} & 0.95 & 0.98 & 1.12 & 1.19 & 1.18 & 1.20 \\
\hline & 0.146 & 0.125 & 0.138 & 0.144 & 0.112 & 0.127 \\
\hline \multirow[t]{2}{*}{ Digestible OM, kg } & 0.61 & 0.63 & 0.72 & 0.95 & 0.96 & 0.97 \\
\hline & 0.095 & 0.081 & 0.089 & 0.105 & 0.087 & 0.100 \\
\hline \multirow[t]{2}{*}{ Net energy, FFU } & 0.75 & 0.80 & 0.93 & 1.21 & 1.25 & 1.28 \\
\hline & 0.105 & 0.102 & 0.114 & 0.125 & 0.110 & 0.126 \\
\hline \multirow{2}{*}{ ME, FU } & 0.82 & 0.85 & 0.97 & 1.28 & 1.30 & 1.32 \\
\hline & 0.126 & 0.108 & 0.120 & 0.14 & 0.12 & 0.13 \\
\hline \multirow[t]{2}{*}{ ME, MJ } & 9.58 & 9.96 & 11.33 & 14.97 & 15.21 & 15.46 \\
\hline & 1.473 & 1.268 & 1.399 & 1.641 & 1.378 & 1.572 \\
\hline \multirow[t]{2}{*}{ Crude protein, $g$} & 162 & 176 & 205 & 156 & 181 & 197 \\
\hline & 20.7 & 21.3 & 25.1 & 17.9 & 16.4 & 19.7 \\
\hline \multirow[t]{2}{*}{ AAT, $g$} & 87 & 94 & 109 & 117 & 126 & 131 \\
\hline & 12.0 & 11.7 & 13.3 & 12.5 & 11.2 & 13.0 \\
\hline \multirow[t]{2}{*}{ PBV, $g$} & 12 & 19 & 26 & -47 & -32 & -22 \\
\hline & 2.7 & 3.3 & 3.5 & 5.1 & 3.1 & 2.8 \\
\hline
\end{tabular}

$\mathrm{L}=$ low; $\mathrm{S}=$ standard; $\mathrm{H}=\mathrm{high}$; $\mathrm{DM}=$ dry matter; $\mathrm{FFU}=$ fattening feed unit $(0.7 \mathrm{~kg}$ starch equivalent $) ; \mathrm{ME}=$ metabolizable energy; FU=feed unit (ME MJ/11.7); AAT= amino acids absorbed from the small intestine; $\mathrm{PBV}=$ protein balance in the rumen.

replacement ewe lambs, only official recommendations for fattening lambs (Salo et al. 1990, Tuori et al. 1996). For a growth rate of 0.2-0.3 $\mathrm{kg} /$ day a $30 \mathrm{~kg}$ fattening lamb is considered to require 0.76-0.96 FFU (Salo et al. 1990), 0.981.25 FU and 86-112 g AAT a day (Tuori et al. 1996). When calculated according to the old feed evaluation system (Salo et al. 1990), the energy intake in this study was sufficient for a growth rate of $0.2 \mathrm{~kg} /$ day on all diets, but on a new system basis (Tuori et al. 1996) the energy intakes from $\mathrm{L}$ and $\mathrm{S}$ diets were below predicted recommendations (NRC 1985, Tuori et al. 1996). According to Tuori et al. (1996), all ewe lambs did satisfy their protein (AAT) needs for a growth rate of $0.2 \mathrm{~kg}$ /day whereas, according to NRC (1985), the ewe lambs on L and S diets experi- enced a crude protein deficiency of 12.4 and $4.9 \%$, respectively.

During mating total DM intakes were 74, 70 and $67 \mathrm{~g} / \mathrm{kgW}^{0.75}$ on L, S and $\mathrm{H}$ diets, respectively. Energy intake averaged 15.2 ME MJ/lamb/ day and was almost equal on all diets. Due to the experimental policy there were differences in protein intakes between diets. According to NRC (1985), a $50 \mathrm{~kg}$ ewe requires daily $150 \mathrm{~g}$ $\mathrm{CP}$ for mating. In this study, the ewe lambs satisfied their protein need on all diets. In Finland, however, there are no standards for combined maintenance and flushing of growing ewe lambs. The calculated total AAT intakes during mating exceeded the feeding recommendationds for a $45 \mathrm{~kg}$ lamb with a daily growth rate of $200 \mathrm{~g}$ (Tuori et al. 1996) by $43 \%$ on average, but the 
Sormunen-Cristian, R. \& Jauhiainen, L. Feeding levels during the growing phase of Finnish landrace ewes

Table 3. Daily nutrient intake of primiparous ewes during 8 weeks pre-partum and lactation. In each figure pair, the upper figure is the mean and the lower is the standard deviation.

\begin{tabular}{|c|c|c|c|c|c|c|}
\hline \multirow{3}{*}{$\begin{array}{l}\text { Diet } \\
\text { Number of ewes }\end{array}$} & \multicolumn{3}{|c|}{8 weeks pre-partum } & \multicolumn{3}{|c|}{ 8-week lactation } \\
\hline & $\mathrm{L}$ & $\mathrm{S}$ & $\mathrm{H}$ & $\mathrm{L}$ & $\mathrm{S}$ & $\mathrm{H}$ \\
\hline & 8 & 9 & 6 & 8 & 9 & 6 \\
\hline \multirow[t]{2}{*}{ Forage, $\mathrm{kg}$ DM } & 0.71 & 0.65 & 0.60 & 1.05 & 1.05 & 1.03 \\
\hline & 0.167 & 0.120 & 0.184 & 0.226 & 0.131 & 0.068 \\
\hline \multirow[t]{2}{*}{ Total DM, kg } & 1.15 & 1.13 & 1.13 & 1.66 & 1.76 & 1.81 \\
\hline & 0.168 & 0.123 & 0.187 & 0.256 & 0.147 & 0.151 \\
\hline \multirow[t]{2}{*}{ Organic matter $(\mathrm{OM}), \mathrm{kg}$} & 1.08 & 1.07 & 1.07 & 1.54 & 1.64 & 1.69 \\
\hline & 0.155 & 0.114 & 0.174 & 0.243 & 0.136 & 0.153 \\
\hline \multirow[t]{2}{*}{ Digestible OM, kg } & 0.77 & 0.77 & 0.78 & 1.10 & 1.18 & 1.22 \\
\hline & 0.102 & 0.075 & 0.114 & 0.168 & 0.100 & 0.124 \\
\hline \multirow[t]{2}{*}{ Net energy, FFU } & 0.89 & 0.90 & 0.92 & 1.21 & 1.32 & 1.38 \\
\hline & 0.099 & 0.074 & 0.110 & 0.180 & 0.125 & 0.172 \\
\hline \multirow[t]{2}{*}{$\mathrm{ME}, \mathrm{FU}$} & 1.03 & 1.03 & 1.04 & 1.45 & 1.56 & 1.63 \\
\hline & 0.133 & 0.080 & 0.148 & 0.222 & 0.134 & 0.169 \\
\hline \multirow[t]{2}{*}{$\mathrm{ME}, \mathrm{MJ}$} & 12.03 & 12.00 & 12.22 & 17.02 & 18.28 & 19.01 \\
\hline & 1.551 & 1.143 & 1.732 & 2.593 & 1.572 & 1.980 \\
\hline \multirow[t]{2}{*}{ Crude protein, $\mathrm{g}$} & 165 & 167 & 173 & 232 & 253 & 266 \\
\hline & 17.3 & 13.4 & 19.7 & 34.4 & 23.9 & 32.1 \\
\hline \multirow[t]{2}{*}{ AAT, g } & 99 & 100 & 104 & 139 & 151 & 158 \\
\hline & 10.9 & 8.3 & 12.4 & 20.6 & 14.1 & 19.1 \\
\hline \multirow[t]{2}{*}{ PBV, g } & -16 & -14 & -11 & -24 & -23 & -26 \\
\hline & 5.4 & 3.7 & 5.9 & 6.2 & 3.8 & 2.9 \\
\hline
\end{tabular}

L=low; S=standard; H=high; DM=dry matter; FFU=fattening feed unit ( $0.7 \mathrm{~kg}$ starch equivalent); ME= metabolizable energy; FU=feed unit (ME MJ/ 11.7); AAT= amino acids absorbed from the small intestine; PBV=protein balance in the rumen.

energy intake (ME MJ) was $4 \%$ below recommendations.

During the last 2 months of pregnancy, ewe lambs on L diet tended to eat more than those on $\mathrm{S}$ and $\mathrm{H}$ diets in proportion to live weight (53, 50 and $47 \mathrm{~g} \mathrm{DM} / \mathrm{kgW}^{0.75}$, respectively). The highest individual DM intake occurred in one $\mathrm{L}$ ewe 2 weeks before parturition (1.59 kg DM/ewe/ day). The result agreed with McNeill et al. (1998) who found that lean ewes had a higher voluntary feed intake than fatter ewes in late pregnancy. The calculated protein balance in the rumen (PBV) was negative on all diets (Table 3).

During lactation, the differences in energy and protein intakes between ewes on $\mathrm{S}$ and $\mathrm{H}$ diets were smaller than those on $\mathrm{S}$ and $\mathrm{L}$ diets. The negative protein balance value (PBV) in the rumen on all diets suggested that the microbial protein synthesis was constrained by dietary nitrogen supply. The recommended PBV intake falls between 0 and $-20 \mathrm{~g}$ for twin-suckled ewes (Havrevoll et al. 1992). In Norway it is recommended to give $70 \mathrm{~g}$ AAT for producing a kilogram of milk, which is equivalent to $200 \mathrm{~g}$ of daily gain in lambs (Lind et al. 1998). To meet the nutrient recommendations for lactation, twinsuckled ewes weighing 50-60 kg should be fed daily levels providing on average 26.1 ME MJ, $224 \mathrm{~g} \mathrm{AAT}$ and $372 \mathrm{~g}$ CP (Tuori et al. 1996). Ewes on all diets experienced an energy and protein deficiency with energy and protein intakes of $27-35 \%$ and $29-37 \%$ below recommended levels, respectively. 
Vol. 9 (2000): 187-200.

Table 4. Live weights of ewe lambs (LS means) at selected points of rearing, mating, pregnancy and lactation.

\begin{tabular}{|c|c|c|c|c|c|c|c|}
\hline \multirow[b]{2}{*}{ Diet } & \multirow[b]{2}{*}{$\mathrm{L}$} & \multirow[b]{2}{*}{ S } & \multirow[b]{2}{*}{$\mathrm{H}$} & \multirow[b]{2}{*}{ SEM } & \multicolumn{3}{|c|}{ Significance } \\
\hline & & & & & Lvs. S & L vs. H & S vs. H \\
\hline \multicolumn{8}{|l|}{ Live weight of ewes, $\mathrm{kg}$} \\
\hline At birth & 3.0 & 3.1 & 3.1 & 0.18 & 0.56 & 0.69 & 0.85 \\
\hline At weaning ( 8 weeks) & 19.0 & 19.1 & 19.4 & 1.13 & 0.93 & 0.81 & 0.87 \\
\hline At 23 weeks & 37.0 & 39.7 & 43.5 & 1.60 & 0.22 & $<0.01$ & 0.09 \\
\hline At mating & 47.8 & 51.3 & 54.1 & 1.72 & 0.16 & 0.01 & 0.22 \\
\hline 56 days pre-partum & 57.1 & 60.5 & 65.9 & 1.90 & 0.20 & $<0.005$ & 0.05 \\
\hline 28 days pre-partum & 58.5 & 61.9 & 67.7 & 2.13 & 0.28 & $<0.01$ & 0.06 \\
\hline 1 day pre-partum & 63.0 & 66.8 & 73.4 & 2.32 & 0.25 & $<0.005$ & 0.05 \\
\hline 2 days post-partum & 53.3 & 57.7 & 57.3 & 1.76 & 0.09 & 0.13 & 0.86 \\
\hline 28 days post-partum & 50.5 & 56.7 & 59.2 & 2.17 & 0.05 & $<0.01$ & 0.42 \\
\hline 56 days post-partum & 50.2 & 54.9 & 59.7 & 2.22 & 0.14 & $<0.01$ & 0.13 \\
\hline \multicolumn{8}{|l|}{ Live weight change, $\mathrm{kg}$} \\
\hline Weaning to 23 weeks & 18.0 & 20.6 & 24.1 & 0.71 & 0.01 & $<0.0001$ & $<0.005$ \\
\hline Mating to 1 day pre-partum & 15.2 & 15.5 & 19.2 & 0.97 & 0.83 & $<0.01$ & 0.01 \\
\hline At lambing & -9.7 & -9.1 & -16.1 & 1.10 & 0.67 & $<0.0005$ & $<0.0001$ \\
\hline Lambing to 56 days post-partum & -3.1 & -2.8 & 2.4 & 1.13 & 0.83 & $<0.005$ & $<0.005$ \\
\hline
\end{tabular}

$\mathrm{L}=$ low; $\mathrm{S}=$ standard; $\mathrm{H}=$ high; $\mathrm{SEM}=$ max. standard error of diet means.

\section{Live weights of ewe lambs}

Live weights and changes in live weights during the entire experiment were affected by diet (Table 4). Initial live weights at weaning were similar among the feeding groups and averaged $19.2 \mathrm{~kg}$ (SEM 0.63). From weaning to 23 weeks of age, ewe lambs on $\mathrm{L}, \mathrm{S}$ and $\mathrm{H}$ diets gained on average 170, 195 and $230 \mathrm{~g} / \mathrm{lamb} /$ day, respectively. The growth rates were in agreement with NRC (1985) which recommends a growth rate of 182-227 g/lamb/day for breeding lambs with a live weight of $30-40 \mathrm{~kg}$. Differences in live weight changes during rearing were statistically significant $(\mathrm{P}<0.001)$. In contrast to our results, Christenson et al. (1976) found that weight gains during the growing period were greater for ewe lambs fed the $11 \%$ CP diet than for those fed 13 to $15 \%$ as a result of higher ad libitum intake of the low protein diet than of the higher protein diets. According to recommendations (Tuori et al. 1996), ewe lambs on $L$ and $S$ diets did not satisfy their energy requirements (ME MJ) dur- ing rearing but, except for ewes on $\mathrm{L}$ diets, were able to increase their live weight by about 200 $\mathrm{g} / \mathrm{lamb}$ /day. Thus, in view of reasonable weight gain, the Finnish recommendations for fattening lambs were considered to be unnecessarily high for replacement ewe lambs.

At the beginning of the mating period, the live weights on $\mathrm{L}, \mathrm{S}$ and $\mathrm{H}$ diets averaged 47.8 (SEM 1.72), 51.3 (SEM 1.61) and 54.1 (SEM 1.62) $\mathrm{kg}$, respectively. The importance of live weight as a factor affecting the attainment of puberty has been reported widely. Among others, Keane (1976) has postulated the existence of a threshold live weight below which puberty will not occur. According to Christenson et al. (1976) and NRC (1985), Finnish cross-bred ewe lambs should be fed levels that will result in lambs weighing a minimum of $40-43 \mathrm{~kg}$ at breeding. In the present study, the live weights at mating averaged $51.1 \mathrm{~kg}$ (95\% confidence interval from 49.1 to $53.1 \mathrm{~kg}$ ), i.e. $72 \%$ of adult body weight (Savolainen 1998). The commonly used recommendation is that ewe lambs should have attained 


\section{AGRICULTURAL AND FOOD SCIENCE IN FINLAND}

Sormunen-Cristian, R. \& Jauhiainen, L. Feeding levels during the growing phase of Finnish landrace ewes

two-thirds of their mature weight before exposure for breeding.

It is generally assumed that adult ewes in good physical condition at mating can lose some weight in the second and third months of pregnancy (Wilkinson and Chestnutt 1988). In the present study, live weight gains during the first three months of pregnancy varied from 9.2 (17.9\% of body weight) to $11.8 \mathrm{~kg}(21.8 \%)$ for $\mathrm{S}$ and $\mathrm{H}$ diets, respectively. According to NRC (1985), sufficient additional feed for replacement lambs should be provided to meet weight gains of 0.12 to $0.16 \mathrm{~kg}$ /day during the entire pregnancy. In agreement with NRC (1985), ewe lambs on L, S and $\mathrm{H}$ diets gained on average $0.11,0.11$ and 0.13 $\mathrm{g} / \mathrm{lamb} /$ day, respectively. The similarity of mean live weight gains between groups of ewe lambs in late pregnancy indicated similar nourishment. When fed high levels throughout, ewes lost weight most at lambing due to a higher prolificacy. Although ewes did not satisfy their energy and protein needs during lactation, they were able to maintain their body weight. Therefore, the Finnish recommendations (Tuori et al. 1996) were concluded be unnecessarily high for ewes lactating for the first time.

\section{Mating and lambing performance}

After the start of mating, ewe lambs on L, S and $\mathrm{H}$ diets conceived in 14, 9 and 6.5 days on average, respectively. This was in accord with Dickerson and Laster (1975) who reported that live weight gain in the first 5 months of life was of great importance to the occurrence of puberty.

Athough energy intakes during rearing and mating on $\mathrm{L}$ and $\mathrm{S}$ diets were below recommendations (Tuori et al. 1996), they appeared to be sufficient for ewe lambs on the S diet, since the conception rate was good. One ewe lamb on the L diet totally failed to exhibit oestrus and two others returned to service. In addition, one ewe on L diet was later found to be barren. Dietary factors have had contradictory effects on reproductive performance (Christenson et al. 1976, Stoerger et al. 1976, Quirke 1979).
The tendency within a mature ewe flock for heavier ewes to have higher ovulation rates which result in more lambs per ewe was found to be true among ewe lambs on the $\mathrm{H}$ diet. Oneyear old Finnish Landrace ewes produce 1.7 lambs/ewe on average (Savolainen 1998), whereas prolificacy was higher in this study, averaging 2.4 lambs/ewe (Table 5). Lambing difficulty was not a problem in the ewes since the lambs born were small in size. According to Christenson et al. (1976), Finnish Landrace ewes lambing at 1 year of age require close management during and after lambing, or lamb losses may be excessive. The length of gestation averaged 143.7 (SD 1.68) days, being shorter than reported by Shrestha and Heaney (1990) in twinbearing Finnish Landrace ewes (144.3 days).

\section{Milk yield}

Analyses of milk yield included only the ewes suckling twins. Thus three ewes, one from each diet, were omitted. There were only slight differences between diets in the shape of lactation curves (diet $\mathrm{x}$ week interaction, $\mathrm{P}=0.04$ ), with more prominent peaks on the curves of ewes on the $\mathrm{H}$ diet. In accordance with Gibb and Treacher (1982), milk production peaked in the third and fourth lactation week (Table 6). Consistent with earlier results (Sormunen-Cristian et al. 1997), twin-suckled ewes on the S or L diet tended to produce more milk (11.6 and $4.1 \%$ ) than those on the $\mathrm{H}$ diet, but the differences between diets were not statistically significant. Umberger et al. (1985) found that intensive feeding during rearing had a negative effect on the milk production of ewe lambs at maturity. In the study of Umberger (cited by Johnsson and Hart 1985), female lambs fed to grow about $200 \mathrm{~g} /$ day from early weaning to first mating at 9 months of age had a lower and less persistent milk yield in their first lactation than contemporaries reared to grow about 100 g/day. However, NRC (1985) recommends feeding levels for ewe lambs that will result in a higher daily growth rate. Johnsson and Hart (1985) suggested that the significant reduc- 
Vol. 9 (2000): 187-200.

Table 5. Mean diet effects on lambing performance.

\begin{tabular}{lccc}
\hline Diet & Low & Standard & High \\
\hline Number of ewe lambs exposed & 10 & 10 & 9 \\
Number of lambing ewes & \multicolumn{1}{c}{${ }^{1}$} & 9 & 6 \\
Number of ewes: & 8 & 1 & 0 \\
$\quad$ Single births & 1 & 7 & 1 \\
$\quad$ Twin births & 4 & 1 & 5 \\
$\quad$ Triplet- quadruplet births & 3 & 2.0 & 3.0 \\
$\quad$ Prolificacy (lambs/ewe lambed) & 2.3 & $0 / 18$ & $2 / 18$ \\
Birth mortality (dead/born) & $0 / 18$ & $1 / 18$ & $5 / 16$ \\
Artificial rearing (transferred/alive) & $3 / 18$ & 1.9 & 1.8 \\
Rearing type (lambs reared/ewe) & 1.9 & &
\end{tabular}

${ }^{1}$ Ewes eliminated or dead during pregnancy were excluded.

tion in milk yield reported as a result of a high level of feeding can be explained in terms of impairment of prepubertal mammogenesis. Large differences in the level of nutrition after 9 months of age, when the ewes were pregnant, had no effect on the subsequent milk yield in the study of Umberger (cited by Johnsson and Hart 1985).

During the 8-week lactation ewes on L, S and $\mathrm{H}$ diets nursing twins produced on average 2.06, 2.20 and $1.98 \mathrm{~kg}$ of milk per day, respectively. Compared with adult Finnish Landarce ewes
(Sormunen-Cristian et al. 1997), the milk yield of primiparous ewes was $39 \%$ lower. According to Treacher (1978), the milk yield of a ewe lambing for the first time at 1 year of age is substantially low. Milk yields increase from the first to second lactation by $25-45 \%$ (Treacher 1978). Maximum milk yield occurs in the third lactation (Boyazoglu 1963, Cappio-Borlino et al. 1997). In this study, milk yield was measured by the oxytocin method which might overestimate the production as reported by Bencini et al. (1992).

Table 6. Eight-hour milk yield (g) of twin-suckled primiparous ewes fed low (L), standard (S) and high (H) levels.

\begin{tabular}{|c|c|c|c|c|c|c|c|}
\hline \multirow[b]{2}{*}{ Week } & \multicolumn{3}{|c|}{ Diet } & \multirow[b]{2}{*}{ SEM } & \multicolumn{3}{|c|}{ Significance } \\
\hline & $\mathrm{L}$ & $\mathrm{S}$ & $\mathrm{H}$ & & L vs. S & L vs. H & $\mathrm{S}$ vs. $\mathrm{H}$ \\
\hline 1 & 624 & 635 & 505 & 73.9 & 0.90 & 0.21 & 0.18 \\
\hline 2 & 731 & 750 & 587 & 73.9 & 0.83 & 0.14 & 0.09 \\
\hline 3 & 763 & 790 & 759 & 73.9 & 0.76 & 0.96 & 0.75 \\
\hline 4 & 766 & 795 & 732 & 73.9 & 0.73 & 0.72 & 0.51 \\
\hline 5 & 740 & 754 & 748 & 73.9 & 0.86 & 0.93 & 0.95 \\
\hline 6 & 651 & 735 & 715 & 73.9 & 0.33 & 0.50 & 0.84 \\
\hline 7 & 629 & 722 & 651 & 73.9 & 0.28 & 0.82 & 0.45 \\
\hline 8 & 592 & 660 & 581 & 73.9 & 0.42 & 0.91 & 0.41 \\
\hline Mean & 687 & 730 & 660 & 65.9 & 0.58 & 0.75 & 0.42 \\
\hline
\end{tabular}

Number of ewes per L, S and H diet = 7, 8 and 5, respectively; SEM=max. standard error of means. 
Sormunen-Cristian, R. \& Jauhiainen, L. Feeding levels during the growing phase of Finnish landrace ewes

Table 7. Milk fat and protein content (g/kg milk) in twin-suckled ewes fed low (L), standard (S) and high (H) levels.

\begin{tabular}{|c|c|c|c|c|c|c|c|c|c|c|c|c|c|c|}
\hline \multirow[b]{3}{*}{ Week } & \multicolumn{7}{|c|}{ Milk fat } & \multicolumn{7}{|c|}{ Milk protein } \\
\hline & \multicolumn{3}{|c|}{ Diet } & \multirow[b]{2}{*}{ SEM } & \multicolumn{3}{|c|}{ Significance } & \multicolumn{3}{|c|}{ Diet } & \multirow[b]{2}{*}{ SEM } & \multicolumn{3}{|c|}{ Significance } \\
\hline & $\mathrm{L}$ & $\mathrm{S}$ & $\mathrm{H}$ & & $\mathrm{P} 1$ & $\mathrm{P} 2$ & P3 & $\mathrm{L}$ & $\mathrm{S}$ & $\mathrm{H}$ & & $\mathrm{P} 1$ & $\mathrm{P} 2$ & $\mathrm{P} 3$ \\
\hline 1 & 89 & 86 & 82 & 4.4 & 0.68 & 0.10 & 0.43 & 48.2 & 48.5 & 49.0 & 2.83 & 0.93 & 0.84 & 0.90 \\
\hline 2 & 87 & 78 & 71 & 4.4 & 0.09 & $<0.01$ & 0.22 & 44.4 & 46.4 & 43.1 & 1.52 & 0.24 & 0.52 & 0.10 \\
\hline 3 & 85 & 79 & 71 & 4.4 & 0.20 & $<0.01$ & 0.10 & 42.8 & 46.7 & 43.7 & 1.52 & 0.03 & 0.67 & 0.13 \\
\hline 4 & 83 & 74 & 74 & 4.4 & 0.09 & 0.11 & 0.94 & 42.9 & 46.9 & 45.0 & 1.39 & 0.01 & 0.24 & 0.27 \\
\hline 5 & 84 & 74 & 72 & 4.4 & 0.06 & 0.04 & 0.67 & 42.9 & 47.0 & 45.4 & 1.30 & $<0.01$ & 0.13 & 0.36 \\
\hline 6 & 82 & 72 & 70 & 4.4 & 0.04 & 0.04 & 0.84 & 44.9 & 46.7 & 45.7 & 1.34 & 0.24 & 0.63 & 0.57 \\
\hline 7 & 84 & 71 & 72 & 4.4 & 0.01 & 0.03 & 0.91 & 45.5 & 47.8 & 47.1 & 1.13 & 0.13 & 0.33 & 0.68 \\
\hline 8 & 86 & 77 & 77 & 4.4 & 0.10 & 0.15 & 0.96 & 48.1 & 48.0 & 46.8 & 1.48 & 0.99 & 0.92 & 0.93 \\
\hline
\end{tabular}

Number of ewes per L, S and $\mathrm{H}$ diet $=7,8$ and 5, respectively; SEM=max. standard error of means; P1= L vs. S, P2=L vs. $\mathrm{H}, \mathrm{P} 3=\mathrm{S}$ vs. $\mathrm{H}$.

Throughout lactation, ewes on the $\mathrm{L}$ and $\mathrm{S}$ diets lost weight, indicating that milk production was partially supported at the expense of stored body tissue. In some instances, a slight restriction of nutrient intake in lactating ewes may not greatly reduce milk production, but it may result in the loss of body weight and body reserves (Peart 1982).

\section{Milk composition}

The level of feeding had a marked effect on the fat content of milk. Milk fat was highest on the $\mathrm{L}$ and lowest on the $\mathrm{H}$ diet (Table 7). Differences between the $\mathrm{S}$ and $\mathrm{H}$ diets were not significant. Compared to the milk produced by adult Finnish Landrace ewes (Sormunen-Cristian et al. 1997), the average fat content was 1.3-2.4 percentage points higher in this study. On the contrary, Gonzalo et al. (1993) found that the fat percentage increased with increasing parity. In the study of Cappio-Borlino et al. (1997), fat percentages were equal in the first and second parity, but significantly higher in the third parity.

The differences in protein content between diets varied from week to week $(\mathrm{P}=0.04)$. In agreement with Cappio-Borlino et al. (1997), the lowest point of the protein curve, when detecta- ble, occurred at approximately the same time as peak milk yield. The protein content was highest on the $\mathrm{S}$ diet and varied less than that on the other diets. On the $\mathrm{L}$ diet the protein content declined in early lactation to a minimum level $(42.9 \mathrm{~g} / \mathrm{kg}$ milk) in weeks 3 to 5 and thereafter increased steadily, regaining the initial level at the end of lactation $(48.1 \mathrm{~g} / \mathrm{kg}$ milk). Variations in protein content between ewes were small. In agreement with Cappio-Borlino et al. (1997), the average protein percentage was less than that of adult ewes (Sormunen-Cristian et al. 1997). The lower protein percentage of milk for ewes during the first lactation was probably related to the reduced rumen functionality and synthesis efficiency of the mammary gland and to preferential utilization of amino acids by growing tissues (Cappio-Borlino et al. 1997).

\section{Lamb performance}

The birth weight and postnatal growth of twin lambs to the age of 8 weeks were not affected by diet (Table 8 ). Inconsistently, Wilkinson and Chestnutt (1988) reported that the higher level of nutrition in late pregnancy resulted in higher ewe live weights as well as higher lamb birth weights. The total lamb birth weights were high- 
Vol. 9 (2000): 187-200.

Table 8. Mean diet effects on weight and growth rate of twin lambs.

\begin{tabular}{|c|c|c|c|c|c|c|c|}
\hline \multirow[b]{2}{*}{ Diet } & \multicolumn{3}{|c|}{ Diet } & \multirow[b]{2}{*}{ SEM } & \multicolumn{3}{|c|}{ Significance } \\
\hline & $\mathrm{L}$ & $\mathrm{S}$ & $\mathrm{H}$ & & L vs. S & L vs. H & S vs. H \\
\hline Litter weight, $\mathrm{kg}$ & 5.8 & 5.4 & 7.2 & 0.60 & 0.58 & 0.09 & 0.03 \\
\hline \multicolumn{8}{|l|}{ Live weight of twins, $\mathrm{kg}$} \\
\hline - at birth & 2.7 & 2.6 & 2.9 & 0.17 & 0.78 & 0.45 & 0.31 \\
\hline - at 2 weeks & 4.8 & 4.7 & 4.6 & 0.27 & 0.68 & 0.46 & 0.70 \\
\hline - at 4 weeks & 6.8 & 6.9 & 6.6 & 0.36 & 0.82 & 0.70 & 0.55 \\
\hline - at 6 weeks & 9.4 & 9.8 & 9.7 & 0.52 & 0.57 & 0.70 & 0.91 \\
\hline - at 8 weeks & 12.9 & 13.5 & 13.5 & 0.80 & 0.57 & 0.62 & 0.99 \\
\hline Weight gain of twins, g/day & 179 & 189 & 185 & 15.4 & 0.48 & 0.70 & 0.80 \\
\hline
\end{tabular}

$\mathrm{L}=$ low; $\mathrm{S}=$ standard; $\mathrm{H}=$ high $\mathrm{SEM}=\max$. standard error of means.

er for ad libitum fed ewes than for ewes restricted to 87.5 and $75 \%$ ad libitum feeding (Christenson et al. 1976). In contrast, a negative relationship between nutrition level in mid-pregnancy and lamb birth weight was reported by Robinson (1977). The lambs in the present study weighed at weaning $5.3 \mathrm{~kg}$ less on average than their dams at the same age. The difference in live weight was explained by a better milk yield of the adult ewes which reared the dams. However, the mean value for the conversion efficiency of milk to live weight gain $(0.178 \mathrm{~kg}$ live weight gain for each $\mathrm{kg}$ fresh milk intake) was consistent with the observations of Boyazoglu (1963).

\section{Health of experimental ewes}

The ewe lambs on $\mathrm{S}$ diet were healthier than those on the other diets. Only one ewe aborted; this occurred on the $\mathrm{S}$ diet about 30 days before lambing and the ewe was eliminated from the study. In total, four ewe lambs on the $\mathrm{H}$ diet were culled due to vaginal prolapses (three cases) and leg injury. The first cervical prolapse occurred before mating and the subsequent ones 70 and 120 days after mating, respectively. This finding agreed with Wilkinson and Chestnutt (1988), indicating that prolapses might be more likely to occur where more concentrate is offered and the ewe has excess fat. Because the cervical pro- lapse is due primarily to lack of space within the ewe, especially in multiparous ewes, it has also been suggested that hay should be restricted or withheld during the last month of pregnancy. In addition, one ewe lamb on the $\mathrm{H}$ diet suffered from laminitis, but she recovered. On the $\mathrm{L}$ diet, one ewe lamb failed to exhibit oestrus, another was found to be barren and the third one was eliminated due to leg injury. Just before lambing ewes on the $\mathrm{H}$ diet were more than $10 \mathrm{~kg}$ heavier than those on the L diet. Oddy and Holst (1991) suggested that fat ewes were susceptible to reductions in feed intake in late pregnancy, making them more prone to hypoglycaemia. However, in the present study, no health problems occurred at lambing. Mastitis was not observed.

\section{Conclusions}

A study was carried out to test whether replacement ewe lambs of the Finnish Landarce breed reared as intensively as fattening lambs tended to have lower productive performance as primiparous ewes. Feeding prepubertal ewe lambs according to the energy and protein standards of fattening lambs had no detrimental impact on their milk yield, the protein content of their milk 


\section{AGRICULTURAL AND FOOD SCIENCE IN FINLAND}

Sormunen-Cristian, R. \& Jauhiainen, L. Feeding levels during the growing phase of Finnish landrace ewes

or on the growth rate of their lambs. It is suggested that since productive performance was not reduced, replacement ewe lambs can be reared together with market lambs. Furthermore, the current data indicates that the official Finnish feeding recommendations for sheep are unnecessarily high and therefore need to be revised.
However, additional studies are needed to validate these findings.

Acknowledgements. The authors are grateful to Ms Helvi Kananen and her staff for technical assistance during the experiment. Dr Seija Jaakkola is also acknowledged for her valuable comments and criticism of the current manuscript.

\section{References}

Anderson, R.R. 1975. Mammary gland growth in sheep. Journal of Animal Science 41: 118-123.

AOAC 1984. Official methods of analysis. 14th ed. Association of Official Chemists, Inc., Arlington, Virginia. $1141 \mathrm{p}$

Bencini, R., Martin, G.B., Purvis, I.W. \& Hartman, P.E. 1992. Use of oxytocin to measure milk output in Merino ewes and its effect on fat content. Australian Journal of Experimental Agriculture 32: 601-603.

Boyazoglu, J.G. 1963. Quantitative aspects of milk production in sheep. 1. Bibliographical review. Annales de Zootechia 12: 237-296.

Cappio-Borlino, A., Portolano, B., Todaro, M., Macciotta, N.P.P., Giaccone, P. \& Pulina, G. 1997. Lactation curves of Valle del Belice dairy ewes for yields of milk, fat, and protein estimated with test day models. Journal of Dairy Science 80: 3023-3029.

Christenson, R.K., Laster, D.B. \& Glimp, H.A. 1976. Influence of dietary energy and protein on reproductive performance of Finn-cross ewe lambs. Journal of Animal Science 42: 448-454.

Dickerson, G.E. \& Laster, D.E. 1975. Breed, heterosis and environmental influences on growth and puberty in ewe lambs. Journal of Animal Science 41: 1-9.

Dýrmundsson, Ó.R. 1973. Puberty and early reproductive performance in sheep. I. Ewe lambs. Animal Breeding Abstract 41: 273-289.

Foldager, J. \& Sejrsen, K. 1991. Rearing intensity in heifers and the effect on subsequent milk production. Report no 693 from the National Institute of Animal Science. Denmark. $131 \mathrm{p}$.

Gibb, M.J. \& Treacher, T.T. 1982. The effect of body condition and nutrition during late pregnancy in the performance of grazing ewes during lactation. Animal Production 34: 123-129.

Gonzalo, C., Carriedo, J.A., Baro, J.A. \& Primitivo, F.S. 1993. Factors influencing variation of test day milk yield, somatic cell count, fat, and protein in dairy sheep. Journal of Dairy Science 77: 1537-1542.

Gould, M.B. \& Whiteman, J.V. 1975. Relationship between preweaning growth rate of female lambs and the growth of their offspring. Journal of Animal Science 40: 585-589.

Havrevoll, Ø., Nedkvitne, J.J., Matre, T., Volden, H., Eik,
L.O. \& Berg, J. 1992. Proteinnormer for ungdyr og sau. Husdjurforsøksmøtet, 1992. 671 p.

Johnsson, I.D. \& Hart, I.C. 1985. Pre-pubertal mammogenesis in the sheep. 1. The effects of level of nutrition on growth and mammary development in female lambs. Animal Production 41: 323-332.

Kassem, R., Owen, J.B. \& Fadel, I. 1989. The effect of pre-mating nutrition and exposure to the presence of rams on the onset of puberty in Awassi ewe lambs under semi-arid conditions. Animal Production 48: 393-397.

Keane, M.G. 1976. Breeding from ewe lambs. Farm and Feed Research 7: 10-12.

Lind, V., Nordang, L. \& Todnem, J. 1998. Kraftfor til sau som har lammet. Sau og Geit 51: 54-55.

Maff, 1975. Energy Allowances and Feeding Systems for Ruminants. Technical Bulletin 33. Her Majesty's Stationary Office, London. 79 p.

McCance, I. 1959. The determination of milk yield in the Merino ewe. Australian Journal of Agricultural Research 10: 839-859.

McNeill, D.M., Kelly, R.W. \& Williams, I.H. 1998. Partition of nutrients in moderately fat ewes compared with lean ewes given ad libitum access to feed in late pregnancy. Australian Journal of Agricultural Research 49: 575-580.

Neter, J., Kutner, M., Nachtsheim, C. \& Wasserman, W. 1996. Applied Linear Statistical Models. Fourth Edition. Irwin, Chicago. 1310 p.

NRC 1985. Nutrient Requirements of Sheep. 6 th revised ed. Washington, D.C. 99 p.

Oddy, V.H. \& Holst, P.J. 1991. Maternal-foetal adaptions to mid pregnancy feed restriction in single-bearing ewes. Australian Journal of Agricultural Research 42: 969-978.

Owen, J.B. 1976. Sheep Production. Bailliere Tindall, London. 436 p.

Peart, J.N. 1982. Lactation of suckling ewes and does. In: Coop, I.E. (ed.). Sheep and Goat Production. Elsevier Scientific Publ. Co., New York. p. 119-134.

Quirke, J.F. 1979. Effect of body weight on the attainment of puberty and reproductive performance of Galway and Fingalway female lambs. Animal Production 28: 297-307. 


\section{AGRICULTURAL AND FOOD SCIENCE IN FINLAND}

Vol. 9 (2000): 187-200.

Robinson, J.J. 1977. The influence of maternal nutrition on ovine foetal growth. Proceedings of the Nutrition Society 36: 9-16.

Salo, M.-L., Tuori, M. \& Kiiskinen, T. 1990. Rehutaulukot ja ruokintanormit. Yliopistopaino, Helsinki. 70 p.

Savolainen, U. 1998. Lammastarkkailutulokset 1997. Lammas ja vuohi 2: 10-16.

Shrestha, J.N.B. \& Heaney, D.P. 1990. Genetic basis of variation in reproductive performance. 2. Genetic correlation between gestation length and prolificacy in sheep. Animal Reproduction Science 23: 305-317.

Sormunen-Cristian, R., Ketoja, E. \& Hepola, H. 1997. Sufficiency of the energy and protein standards for lactation of adult multiparous Finnish Landrace ewes. Small Ruminant Research 26: 223-237.

Stoerger, M.F., Hinds, F.C., Lewis, J.M. \& Wallace, M. 1976. Influence of dietary roughage level on reproductive rate in ewe lambs. Journal of Animal Science 43: 952-958.

Treacher, T.T. 1978. The effects on milk production of the number of lambs suckled and age, parity and size of ewe. European Association for Animal Production,
Publication 23: 31-35.

Tuori, M., Kaustell, K., Valaja, J., Aimonen, E., Saarisalo, E. \& Huhtanen, P. 1996. Rehutaulukot ja ruokintasuositukset. Yliopistopaino, Helsinki. 99 p.

Umberger, S.H., Goode, L., Carualo, E.V., Harvey, R.W., Britt, J.H. \& Linnerud, A.C. 1985. Effects of accelerated growth during rearing on reproduction and lactation in ewes lambing at 13 to 15 months of age. Theriogenology 23: 555-564.

Wilkinson, S.C. \& Chestnutt, D.M.B. 1988. Effect of level of food intake in mid and late pregnancy on the performance of breeding ewes. Animal Production 47: 411-419.

Wolfinger, R. 1996. Heterogeneous variance-covariance structures for repeated measures. Journal of Agricultural, Biological, and Environmental Statistics 1: 205-230.

Younis, A.A., Al-Kamali, A.A. \& El-Tawil, E.A. 1978. Effect of flushing on fertility of Awassi and Hamdani ewes. World Review of Animal Production 14: 4148. 


\title{
SELOSTUS
}

\section{Ruokinnan voimakkuuden vaikutus siitosuuhikaritsan tuotantoon}

\author{
Riitta Sormunen-Cristian ja Lauri Jauhiainen \\ Maatalouden tutkimuskeskus
}

Maassamme käytössä olevissa lampaiden ruokintasuosituksissa ei erotella siitos- ja lihakaritsoiden ravinnontarvetta. Keväällä syntyneet, siitokseen jätetyt suomenlammasrotuiset uuhikaritsat kasvatetaankin normaalisti yhdessä lihakaritsoiden kanssa ja ruokitaan myös yhtä voimakkaasti. Siitoskaritsoiden liian voimakas ruokinta ennen puberteettiä ja ensimmäisen tiineyden ja maidontuotantokauden aikana voi kuitenkin heikentää jopa pysyvästi utareen kehitystä ja alentaa eläimen maidontuotantokykyä. Vastaavasti liian niukka ruokinta pidentää kasvatuskautta, lisää ruokintakustannuksia ja aiheuttaa muun muassa tiinehtyvyyshäiriöitä. Sopivana siitoskaritsan kasvunopeutena vieroituksesta astutukseen pidetään noin 200 g päivässä.

Ensi kertaa poikivien suomenlammasrotuisten uuhikaritsoiden ravinnontarvetta ja maidontuotantoa ei aikaisemmin ole tutkittu. Tutkimuksen tarkoituksena oli selvittää ruokinnan voimaperäisyyden vaikutusta siitosuuhikaritsoiden kasvuun, tiinehtyvyyteen, terveyteen, karitsatuotokseen ja maidontuotantoon. Tutkimuksessa oli mukana 31 suomenlammasuuhikaritsaa kolmessa ruokintaryhmässä kahdeksan viikon iästä kahdeksannen maidontuotantoviikon loppuun.

Heinän saanti oli vapaa kaikissa tuotosvaiheissa. Kasvatuskaudella, vieroituksesta 23 viikon ikään ohra-soijaväkirehuseosta annettiin elopainoon suhteutettuna alitusryhmälle $54 \mathrm{~g}$ kuiva-aineena (ka)/metabolinen elopaino-kg $\left(\mathrm{kgW}^{0.75}\right)$, vertailuryhmälle 63 ja ylitysryhmälle $72 \mathrm{~g} \mathrm{ka} / \mathrm{kgW}^{0.75}$. Alitusryhmä sai 14 $\%$ vähemmän ja ylitysryhmä $14 \%$ enemmän valkuaista ja energiaa kuin vertailuryhmä. Astutuskaudel- la kaikki karitsat saivat väkirehua $70 \%$ (54 g ka/ $\mathrm{kgW}^{0.75}$ ) kokonaiskuiva-aineen syönnistä. Tiineyden aikana väkirehumäärä oli 500-600 g/uuhi/päivä ja maidontuotantokaudella 360-480 g/imevä karitsa/päivä.

Kasvatuskaudella alitus-, vertailu- ja ylitysryhmän uuhikaritsat saivat rehuannoksestaan energiaa keskimäärin 0,82, 0,85 ja 0,97 rehuyksikköä, raakavalkuaista 162, 176 ja 205 g sekä ohutsuolessa imeytyviä aminohappoja 87, 94 ja 109 g päivässä. Vastaavana aikana karitsat kasvoivat keskimäärin 170, 195 ja 230 g/karitsa/päivä. Ruokintasuositusten mukaan alitus- ja vertailuryhmän karitsat kärsivät energian vajauksesta kasvatus- ja astutuskaudella. Maidontuotantokaudella kaikkien karitsauuhien energian ja valkuaisen saanti jäi noin 27-37\% alle suositusten. Tuotosten perusteella ravinnonsaanti oli kuitenkin riittävä.

Ylitysryhmän ruokinta nopeutti siitokseen jätettyjen uuhikaritsoiden kiimaantuloa ja tiinehtymistä. Eniten energiaa ja valkuaista saaneilla uuhilla oli myös suurin sikiävyys (4,0 karitsaa/uuhi). Voimakkaan ruokinnan ongelmat olivat luomiset ja jalkasairaudet. Parhaiten maitoa tuottivat vertailuryhmän uuhet. Erot maidontuotannossa eri ruokintaryhmien välillä olivat kuitenkin pienet. Runsas väkirehuruokinta vähensi maidon rasvapitoisuutta, mutta sen vaikutus maidon valkuaispitoisuuteen oli vähäinen.

Tutkimuksen perusteella siitokseen jätetyt suomenlammasuuhikaritsat voidaan kasvattaa yhtä voi-

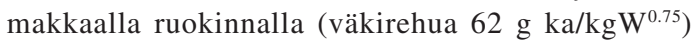
kuin lihakaritsat tuotoksen siitä kärsimättä. Käytössä olevat ruokintasuositukset vaativat tarkentamista. 